\title{
Acute Liver Failure in Rats Induced Vasogenic Edema and Nitric Oxide Synthase-Nitric Oxide- cGMP Pathway after Differential Regulation of NMDA Receptors in Cerebral Cortex and Cerebellum
}

SANTOSH SINGH ( $\square$ santoshbhu@gmail.com)

Guru Ghasidas University https://orcid.org/0000-0003-2308-1483

\section{Arghya Mukherjee}

Guru Ghasidas Vishwavidyalaya: Guru Ghasidas University

Deepika Jeswani

Guru Ghasidas Vishwavidyalaya: Guru Ghasidas University

\section{Research Article}

Keywords: Acute liver failure (ALF), Brain edema, NMDAR (NR2A-D subunits), NOS-NO-cGMP pathway

Posted Date: January 6th, 2022

DOI: https://doi.org/10.21203/rs.3.rs-1224629/v1

License: (c) (i) This work is licensed under a Creative Commons Attribution 4.0 International License.

Read Full License 


\section{Abstract}

Acute liver failure (ALF) is a complication of severe liver dysfunction resulting from a wide range of factors including alcoholism, drug-abuse, improper medication, viral hepatitis etc., and present with high mortality rate among the human population. ALF led hyperammonemia (HA) induced cerebral dysfunction is considered to be the main cause of death in patients, however, the precise molecular mechanism is not completely understood. The aim of this study was to investigate the status of brain edema and modulation of N-methyl D-aspartate receptors (NMDAR)- Nitric oxide synthase (NOS)- Nitric oxide (NO)- cyclic guanosine monophosphate (cGMP) axis in the cerebral cortex and cerebellum of ALF rats. ALF was induced by intraperitoneal (IP) injection of thioacetamide (TAA). We observed significantly increased brain water content in ALF rats but absence of astrocytes swelling suggested induction of vasogenic edema. Except constant NR2B, down regulation of NR2A, $2 \mathrm{C}$ and 2D subunits containing NMDAR genes in cerebral cortex, however, constant NR2A-C but up-regulation of NR2D subunit in cerebellum suggested brain regions specific differential regulation of NMDAR in ALF rats. Significantly increased nNOS gene and protein level were found to be accompanied by the significantly increased level of NO and cGMP in both brain tissues; however, increased eNOS expression in cortex but increased iNOS expression and activity in cerebellum were observed in ALF rats. Together these findings suggested that ALF in rats may trigger differential regulation of NR2A-D subunits containing NMDAR, induction of NOSNO-cGMP axis and vasogenic edema in cerebral cortex and cerebellum.

\section{Introduction}

ALF is defined as a sudden occurrence of massive hepatic cell death with severe liver dysfunction in patients without the prior history of chronic liver diseases (CLD) [1]. It caused the reduced elimination of toxic substances from blood that lead to the multi-organs failure, hepatic encephalopathy (HE), coma and rapid death of the patients [1, 2]. A wide range of etiological factors, including alcoholism, drug-abuse, improper medication, viral hepatitis etc, triggered the differential outcome of ALF and subsequently high mortality rate among ALF patients [2]. Despite several hepatoprotective approaches [3], till date there is no such medication available in the market which could reduce the mortality rate in ALF patients. Liver transplantation has been the only effective primordial treatment of ALF [1]. However, demand of livers is more than available livers for transplantation resulting a long waiting time for patients that led to the death of the patients before finding the suitable livers [4]. Since the liver is very potent in terms of damage healing and regeneration $[5,6]$, it is believed that the main cause of death in ALF patients is not primarily the liver failure but the cerebral dysfunction [2]. Therefore, developing mechanisms to control neurological derangements have been proposed to be beneficial for the patients because it permit the sufficient time either for liver recovery or finding suitable liver for transplantation [7-9]. Moreover, cerebral management also help in improving the quality of life in ALF patients suffering from neuropsychiatric symptoms associated with HE.

The neuropathological mechanisms led to death of ALF patients are not completely understood, however, it is believed that hyperammonemia ( $\mathrm{HA}$ ) mediated brain edema and increased intracranial pressure (IP) 
are the principal immediate causes of mortality in ALF patients. It has been considered that HA led to increased blood-brain barrier (BBB) permeability up to 2-6-fold than normal condition [10,11], results in the brain region specific differential cerebral blood flow (CBF) $[7,8]$ and accumulation of excess amount of water in the extracellular spaces that account for vasogenic edema [10]. Similarly, during brain ammonia metabolism, accumulation of glutamine in astrocytes, manifested by its swelling, consequent to brain regions specific cytotoxic edema $[7,8,11]$. Both cytotoxic and vasogenic edema are known to be contributed in the increased IP and cerebral herniation $[2,7,13]$.

In recent studies, it has been demonstrated that blocking NMDAR by its selective antagonist like MK-801 or memantine delayed or prevented the acute HA and/or ALF induced death in mice and rats [4]. This suggested the important contribution of NMDAR mediated process in the mechanism of HA/ALF induced death. Interestingly, blocking of NMDAR, increased the survival of ALF rats but could not prevent the induction of brain edema, suggesting that brain edema is not the only way of death, other pathways like activation of NMDAR mediated processes contribute in the mechanism of death during ALF. Furthermore, brain edema is not correlated well with the progression HE grades, however, activation of NMDAR is found to be associated with the development of HE grades from I-III [4]. Therefore, it is suggested that brain edema is a NMDAR independent mechanism of death, however, NMDAR dependent process are participated in both inducing acute HE and subsequently death in ALF patients. However, the precise molecular mechanism of NMDAR dependent cerebral derangements in ALF patients is not completely understood and need to be defined in the suitable animal models.

NMDAR are structurally hetero-tetrameric protein complex, comprised of two obligatory glycine binding NR1 subunits and remaining two glutamate binding NR2A-D subunits. It has been observed that NMDA receptor with different NR2 subunits exhibited differential electrophysiological and pharmacological properties [14]. For example, NMDA receptors containing NR2A and NR2B act oppositely to change the direction of hippocampal synaptic plasticity involve in the process of memory consolidation $[14,15]$. In addition, it has been suggested that NMDA receptors containing NR2B subunits induce the neuronal cell death, however, that of NR2A support the cell survival pathway and hence induced the different influence on glutamate excitotoxicity after acute brain injuries such as stroke and trauma [16]. Such opposite function may be one of the reasons of failure of clinical trial for ALF treatments based on blocking NMDAR but give the scientific foundation to develop novel and operative therapy via altering composition of NR2 subunits without un-physiological blocking of NMDAR. Moreover, NR2 subunits expressed heterogeneously in different brain regions as cell specific manners and have differential sensitivity against channel blockers and thus showed distinct channel properties of NMDA receptors. For instance, in comparison to NMDAR containing NR2A and NR2B subunits, NMDAR with NR2C/NR2D subunits have lower sensitivity to $\mathrm{Mg} 2+$ ions and thus absence of desensitization but hold high affinity for glutamate and glycine and therefore NR2D selective antagonists have been found to be prevented their activation by glutamate spill over [17]. Despite of such significance differences in NR2A-D subunits, most of the studies have been done only on NR2B subunits in various neurological diseases including ALF induced cerebral dysfunction. Therefore, it will be crucial to explore the status of different NR2 subunits in distinct brain regions during ALF. 
Now it is evident that nitric oxide synthase (NOS) isoforms at downstream of NMDAR signalling cascade plays important role in neuronal survivability as well as neurodegeneration depending upon the types of NOS isoforms expressions and production of nitric oxide (NO). A physiological concentration of $\mathrm{NO}$ is necessary for maintaining NMDAR dependent NO-cGMP signalling involve in the process of learning and memory [18]. However, augmented NO concentration in the post synaptic neurones has been reported to induce neuronal dysfunctions like neuroinflammation, energy depletion, over production ROS and induction of oxidative stress etc. $[19,20]$. A mild increase in the NO concentration can initiate mitochondrial dysfunction and may led to neuronal apoptosis through alteration of Bcl2-Bax ratio [21]. Previous studies showed that use of specific NOS inhibitors reduce the ammonia toxicity and can also control the progression of brain edema due to traumatic brain injury (TBI) in rat models [22] indicating that NOS would be a key factor in the ALF induced cerebral derangements, however, the exact contribution of different NOS isoforms is still remained to be clarified.

Previously our group has reported that ALF in rats activates glutamine-glutamate cycle and maintain static levels of ammonia and glutamate but reduced antioxidant enzymes to induce oxidative stress in cerebral cortex and cerebellum [28]. In order to understand the effect of ALF on NMDAR and its downstream signalling cascades, in the present study we have investigated the status of different NR2AD subunits genes and their association with the expressions of all NOS isoforms as well as NO-cGMP levels in cerebral cortex and cerebellum of ALF rats. These factors are very crucial to know the actual changes occurs at the molecular level in brain during ALF and subsequently will be contributed in the therapeutic management of ALF patients.

\section{Methodology}

\section{Animals and chemicals:}

Adult male albino rats (Rattus novegicus) weighing 120-150 g were maintained in the animal house in ideal conditions and fed with proper diet as per the recommendation from the institutional animal ethical committee (IAEC) for the care and use of laboratory animals. The use of animal in present study was approved by IAEC, Guru Ghasidas Vishwavidyalaya, Bilaspur, C.G., India (Ref. No. 994/GO/ERe/S/06/CPCSEA). All chemicals used were of analytical grade and of the best quality supplied by SRL (India), Himedia (India), Autospan diagonostic (India) and Sigma chemical co (USA).

\section{(a) Production of Acute liver failure model:}

After proper acclimatization, ALF groups of rats are subjected to the administration thioacetamide (TAA) $(300 \mathrm{mg} / \mathrm{Kg}$ b.w.) prepared in physiological saline $(0.9 \% \mathrm{NaCl})$ interperitoneally daily for consecutive two days for the induction of ALF [23] while at the same time control groups of rats were administered with the equal volume of $0.9 \% \mathrm{NaCl}$. To reduce the hypoglycemia, renal failure and weight loss in the ALF group of rats, $5 \%$ dextrose solution containing $0.45 \% \mathrm{NaCl}$ and $20 \mathrm{meq} / \mathrm{L}$ potassium chloride was mixed with the drinking water and given to the rats [18]. Once the experimental procedure was done, all rats were 
sacrificed and blood sample was collected first from the portal vein for hematopathological studies. Thereafter the organs were collected and stored at $-20^{\circ} \mathrm{C}$ for further tissue processing and experiments.

\section{(b) Hemato-pathological studies:}

The extent of liver damage was determined by measuring the levels of serum sGOT and sGPT. Both sGOT \& sGPT level was measured as per the procedure given in their respective kits supplied by Autospan diagnostic, India. Both blood and brain ammonia and glutamate levels were measured by enzymatic assay kit supplied by Sigma Chemical Co, USA.

\section{(c) Liver histology:}

Liver of the both control and ALF rats were sliced in to small sections $(0.3-0.5 \mathrm{~cm})$ followed by a fixation period of 18-24h using Bouin's solution as fixative. Then tissue slices were subjected to alcoholic dehydration using $70 \%$ ethanol and thereafter embedded in the paraffin wax. Then precise sections $(6 \mu \mathrm{m})$ of the liver was done using microtome and proceed for hematoxylin-eosin (H\&E) staining. Finally, after mounting in xylene the tissue sections were examined under light microscope.

\section{(d) Brain water content:}

Total brain water content was measured by wet/dry weight method [24]. In brief, whole brain tissue were obtained from different groups of rats and their wet weight was measured. Then the tissues were dried in hot air oven at $100^{\circ} \mathrm{C}$ for $48 \mathrm{hrs}$. After complete drying, dry weight was also measured. The percentage of total water content was calculated using the following formula,

Percentage $(\%)$ of total water content $=($ Wet weight - Dry weight $) \times 100$.

Wet weight

\section{(e) Preparation of tissues extracts:}

Both cerebral cortex and cerebellum extracts were made by homogenizing them in $0.02 \mathrm{M}$ Tris $-\mathrm{Cl}(\mathrm{pH}$ 7.4) buffer which contains protease inhibitors as described from our lab. After making $10 \%$ homogenate of cortex and cerebellum separately, they were centrifuged at $12,000 \mathrm{rpm}$ for $15 \mathrm{~min}$ at $4^{0} \mathrm{C}$. At the end of centrifugation, supernatants were collected and preserved at $-80^{\circ} \mathrm{C}$ for future use.

\section{(f) Assay of NO:}

Total level of $\mathrm{NO}\left(\mathrm{NO}_{2} \& \mathrm{NO}_{3}\right)$ of cerebral cortex and cerebellum was estimated by following the protocol given with the kit using Griess reagent, supplied by Himedia Cell Culture.

\section{(g) Assay of inducible NOS:}


iNOS activity was measured spectrophotometrically following the method of Stuehr et al., 1991[25] by observing the oxidation of $\mathrm{NADPH}$ at $\mathrm{pH} 7.9$ in a reaction mixture containing $4 \mu \mathrm{m} \mathrm{BH} 4,4 \mu \mathrm{m} F A D, 3 \mathrm{mM}$ dithiothreitol and $1 \mathrm{mM}$ L-arginine.

\section{(h) Semi-quantitative RT PCR of NMDA and NOS genes.}

- Isolation of total RNA \& DNase I treatment

Total RNA from cerebral cortex and cerebellum were isolated using TRI-reagent (Sigma Chemical Co.) following the user guideline provided by Sigma. In brief, brain tissue was homogenized in 50-100 mg/ml TRI reagent using glass homogenizer to make 10\% homogenate $(1: 10 \mathrm{w} / \mathrm{v})$. Then the homogenate was subjected to centrifugation at $12,000 \mathrm{~g}$ for $15 \mathrm{~min}$ at $4{ }^{0} \mathrm{C}$. Thereafter the supernatant was collected and incubated with the TRI-reagent for $5 \mathrm{~min}$ at room temperature to dissociate nucleoprotein complexes. In the next step the supernatant was added with $0.2 \mathrm{X}(\mathrm{v} / \mathrm{v})$ of chloroform with respect to the starting volume of the homogenate then vortexed and kept at room temperature for $15 \mathrm{~min}$. In the next step the content was further centrifuged at $12,000 \mathrm{~g}$ for $15 \mathrm{~min}$ at $4^{0} \mathrm{C}$ and the colourless upper aqueous phase of the supernatant which containing RNA was taken out in separate tubes. 0.5X initial volume of isopropanol was added to this aqueous phase and kept in the room temperature for 10 min allowing precipitation. Then the precipitated RNA was collected by further centrifugation at $12,000 \mathrm{~g}$ for $10 \mathrm{~min}$ at $4^{0} \mathrm{C}$, followed by washing with $75 \%$ ethanol. Then the pellet was dried for $10 \mathrm{~min}$ and dissolved in DEPC treated water.

Unwanted DNA contaminations (if any) in the RNA preparations was removed by using TURBO DNAfree $^{T M}$ (Ambion). Briefly, total RNA was digested in a $50 \mu$ l reaction mixture containing $20 \mu$ l of total RNA and $0.1 X$ volume of 10X DNase I buffer $(2.5 \mu \mathrm{l}), 2$ units of DNase I $(0.5 \mu \mathrm{l})$ and DEPC $\mathrm{H}_{2} \mathrm{O}(2 \mu \mathrm{l})$, followed by incubation at $37^{\circ} \mathrm{C}$ for $20 \mathrm{~min}$ and thereafter addition of $0.1 \mathrm{X}$ volume of DNase I inactivation reagent slurry $(5 \mu \mathrm{l})$ and incubating the mixture for further $2 \mathrm{~min}$. The mixture was pelleted at 10,000g for $1 \mathrm{~min}$ and the upper phase was collected in small volumes in sterile tubes. The total RNA content was calculated by measuring the absorbance at $260 \mathrm{~nm}$. One unit was taken as equivalent to $40 \mu \mathrm{g}$ of RNA.

\section{- Electrophoresis of RNA}

To check the quality of RNA isolated, RNA samples were subjected to formaldehyde agarose gel electrophoresis following the method as described by Sambrook and Russell, 2001 [26]. 1\% agarose was melted in DEPC treated water at $100^{\circ} \mathrm{C}$ and then cooled up to $60^{\circ} \mathrm{C}$ followed by addition of $10 \mathrm{X}$ MOPS buffer (adjusted to pH-7.0 with $\mathrm{NaOH}$ ) containing 20 mM MOPS, 2 mM Na-acetate, 1mM EDTA \& 2.2 M formaldehyde. The gel was then allowed to polymerize at room temperature. Once the gel was polymerized it was pre-run for $5 \mathrm{~min}$ at $5 \mathrm{~V} / \mathrm{cm}$. The sample containing a total volume of $10 \mu \mathrm{RNA}$ sample containing 2-4 $\mu$ g RNA (adjusted with DEPC treated water) and equal volume of $2 X$ formamide loading dye containing 95\% formamide and 0.025\% each of SDS, bromophenol blue, xylene cyanol FF, EtBr and $0.5 \mathrm{mM}$ EDTA was denatured at $65^{\circ} \mathrm{C}$ for $15 \mathrm{~min}$ was prepared. After completion of pre-run, pre- 
chilled RNA samples were loaded and electrophoresis was carried out at 3-4 V/cm. At the end of the electrophoresis after obtaining intact 28S and 18S RNA bands, RT-PCR of the sample was carried out.

- First strand cDNA synthesis (reverse transcription)

First strand of cDNA was synthesized following the method of cDNA synthesis kit (Fermentas). In brief 2 $\mu \mathrm{g}$ of RNA was mixed with $200 \mathrm{ng}$ of random DNA hexamers in sterile water to make a reaction mixture volume of $12 \mu \mathrm{l}$ followed by incubation at $65^{\circ} \mathrm{C}$ for $5 \mathrm{~min}$ and then chilling on ice to allow the primers to bind with complementary sequences in the RNA. In the next step reagents were added in the following order to make a final volume of $20 \mu \mathrm{l}$ (Please refer Table A).

Reverse transcription was carried out by incubating the reaction mixture for $5 \mathrm{~min}$ at $25^{\circ} \mathrm{C}$ followed by 60 min incubation at $42^{\circ} \mathrm{C}$. The reaction was then terminated by heating the mixture at $70^{\circ} \mathrm{C}$ for $5 \mathrm{~min}$ followed by cooling on ice. 18-20 $\mu \mathrm{l}$ of cDNA sample was added with the equal volume of DEPC treated water to make $2 \mathrm{X}$ diluted $\mathrm{CDNA}$ library and stored at $-70^{\circ} \mathrm{C}$ for $\mathrm{PCR}$ processing.

- PCR amplification of first strand cDNA

$2 \mu \mathrm{l} 2 \mathrm{X}$ cDNA was incubated in a $25 \mu \mathrm{l} \mathrm{PCR}$ reaction mixture consisted of $10 \mathrm{pM} / \mu \mathrm{l}$ for PCR reaction. Each of a primer pairs and reagents supplied with the Taq polymerase as given in Table B.

PCR was performed in a MJ-Mini ${ }^{\mathrm{TM}}$ thermo cycler (BIORAD). The PCR conditions and primers used are given in the Table $\mathrm{C}$.

PCR amplification linearity was checked for each gene and number of cycles from the linear phase of the kinetic plot was chosen for comparing the expression level amongst different experimental groups and $\beta$ actin was used as control for all the RT-PCR experiments.

- Analysis of PCR product

PCR amplified products of the genes along with DNA molecular markers (Gene Ruler ${ }^{\mathrm{TM}} 100 \mathrm{bp}$ Plus DNA Ladder, Fermentas) were resolved by $1.5 \%$ agarose gel electrophoresis. Briefly agarose (1.2-1.5\%) was melted in 1X TAE buffer ( $40 \mathrm{mM}$ Tris, $40 \mathrm{mM}$ acetic acid and $1 \mathrm{mM}$ EDTA), cooled upto $65^{\circ} \mathrm{C}$ followed by addition of $0.5 \mu \mathrm{g} / \mathrm{ml} \mathrm{EtBr}$. In the next step samples were mixed with 6X DNA loading dye containing $30 \%$ glycerol, $0.25 \%$ bromophenol blue and $0.25 \%$ of xylene cyanol. Electrophoresis was run in 1X TAE buffer and the bands were visualized in a UV trans-illuminator and photographed.

\section{(i) Western blotting of nNOS.}

- SDS-PAGE

Proteins in tissue extracts were resolved using SDS-PAGE Laemmli, 1970 [27]. The resolving gels were made of 6-12\% acrylamide: bisacrylamide $29: 1$ ratio ( $\mathrm{v} / \mathrm{v}), 390 \mathrm{mM}$ Tris-Cl $(\mathrm{pH}-8.8), 0.1 \%$ SDS, $0.1 \%$ APS and TEMED. After polymerization of the resolving gel, the stacking gel, containing $5 \%$ acrylamide: 
bisacrylamide (29:1), $125 \mathrm{mM}$ Tris-Cl, 0.1\% SDS, 1\% APS and TEMED, was layered and allowed to polymerize. Denaturation of the extract containing 30-60 $\mu$ g protein was done in $1 \mathrm{X}$ Laemmli sample buffer containing $50 \mathrm{mM}$ Tris-Cl (pH-6.8), 1\% SDS, 1\% $\beta-\mathrm{ME}, 10 \%$ glycerol and $0.1 \%$ bromophenol blue in boiling water bath for $5 \mathrm{~min}$, followed by cooling of the sample on ice and loaded in the wells. An aliquot of protein molecular marker was also loaded in one lane. Electrophoresis was done in a gel running buffer containing $250 \mathrm{mM}$ glycine, $25 \mathrm{mM}$ Tris and $0.1 \%$ SDS at $15 \mathrm{~mA}$ in stacking gel and at $30 \mathrm{~mA}$ in resolving gel until the dye front migrated at bottom of the gel.

- Western transfer and immunodetection

Following SDS-PAGE, the gel was incubated with transfer buffer containing $192 \mathrm{mM}$ glycine pH 8.3, 25 $\mathrm{mM}$ Tris, $0.01 \%$ SDS and $10 \%$ methanol for $10 \mathrm{~min}$. pre-incubated nitrocellulose membrane (with pore size of $0.25 \mu$ ) in the transfer buffer (for $5 \mathrm{~min}$ ) was sandwiched between pre-wetted scotch-bright pads, foams and $3 \mathrm{~mm}$ Whatman filter paper in a Biotech mini-dual wet transfer apparatus. Then the power supply was connected with anode facing membrane and cathode towards the gel and the transfer was carried out overnight (14-16 h) at $4^{0} \mathrm{C}$ with constant power supply of $50 \mathrm{~mA}$. Protein transfer was confirmed by Ponceau S ( $0.5 \%$ Ponceau S, $1 \%$ acetic acid and deionized water) staining followed by distaining of the membrane using deionized water. Thereafter the membrane was blocked in $5 \%$ non-fat milk in PBS ( $\mathrm{pH}-7.4)$ for 4-6h at room temperature, followed by incubation of the blot with the primary antibody diluted in $5 \%$ non-fat milk and $0.1 \%$ Tween -20 in PBS (PBST) overnight at $4^{\circ} \mathrm{C}$. After multiple wash, blot was incubated with HRP conjugated secondary antibody containing PBST for $4 \mathrm{hr}$ at room temperature. Then the blot was washed with PBS and after that protein bands were developed with ECL super signal west Pico kit on X- ray film. To compare between control and ALF groups, protein bands were subjected to densitometry using alphaimager software. For loading control, membranes were re-probed for $\beta$-actin using a monoclonal anti- $\beta$-actin - peroxidase antibody. Details of antibodies processing against different proteins are given in Table $\mathrm{D}$.

\section{(j) Statistical analysis:}

Each experiment was done thrice and each of the sample was taken minimum in four replicas, the data has been presented as mean \pm SD. One way ANOVA was performed using Tukey post hoc analysis method to compare the variance between two groups at a minimum significance level of $0.05(P<0.05)$.

\section{Result}

Assessment of ALF:

ALF was induced by ip injection of TAA concentration of $300 \mathrm{mg} / \mathrm{Kg}$ body weight as described previously. Serum sGOT and SGPT is widely used as LFT markers and hence establishment of ALF was confirmed by measuring these enzyme concentrations in serum. In TAA treated rats, serum sGOT level was found increased $\otimes 11$ fold ( $\left.{ }^{\star \star} p \leq 0.01\right)$ in compare to control rats and sGPT was found to be increased $\otimes 4.7$ folds $\left({ }^{* *} p \leq 0.01\right)$ in ALF rats than control rats (Table 1). Beside this, blood ammonia level was also found 
significantly up regulated in TAA treated rats in compare to control rats up to $₫ 1.6$ fold ( ${ }^{\star} p \leq 0.05$ ) (Table 1). Moreover, liver histological studies also indicate occurrence of centrizonal necrosis in the liver cells (Fig. 1). In addition, serum NO level was also found increased up to $\otimes 2.5$-fold ( ${ }^{\star \star} p \leq 0.01$ ) in TAA treated rats, than control groups of rats (Table 1). Therefore, now it can be stated that the TAA treated rats represents an ideal ALF model.

Brain Parameters:

All though blood ammonia level was found increased significantly but interestingly no significant change in brain ammonia level was observed (Table 2). Likewise, brain ammonia, glutamate level also remains unchanged in both brain regions of ALF rats when compared with control rats (Table 2) but it is notable that glutamine level was found significantly increased $\left({ }^{\star} p \leq 0.05\right)$ in both cerebral cortex and cerebellum of ALF rats (Table 2).

Total water content of brain was found increased up to $2.75 \%$ ( ${ }^{\star \star} p \leq 0.01$ ) in ALF rats (Fig. 2). Increased concentration of water and glutamine but the static level of ammonia and glutamate in brain of ALF group of rats may be an indication of highly adaptation of brain against acute ammonia toxicity.

\section{NMDAR isoforms:}

In comparison to control group, NMDAR containing different NR2 subunits are modulated differentially in cerebral cortex and cerebellum of ALF rats. NR2A (Fig. 3A \& B), NR2C (Fig. 4A \& B) and NR2D (Fig. 4C \& D) genes were down regulated in cortex. However, in cerebellum NR2A (Fig. 3A \& B) and NR2C (Fig. 4A \& B) remained constant but NR2D (Fig. $4 C \& D$ ) increased significantly ( $\left.{ }^{\star \star} p \leq 0.01\right)$. It was notable that there is no significant change found in the expression of NR2B in both brain regions between control and ALF rats (Fig. 3B \& D).

NOS isoforms:

Among the NOS isoforms, when compared with control rats, levels of nNOS genes (Fig. 5A \& B) as well as proteins (Fig. 5C \& D) were found to be significantly increased in both cerebral cortex $\left({ }^{*} p \leq 0.05\right)$ and cerebellum ( $* \star p \leq 0.01$ ) of ALF rats, however, it was noteworthy that cerebellum showed greater upregulation than cortex suggesting differential regulation of nNOS concomitant to NMDAR.

Level of eNOS was found to be up-regulated in the cortex $\left({ }^{* *} p \leq 0.01\right)$ but remain constant in cerebellum of ALF rats (Fig. 7). On the other hand, level of iNOS gene (Fig. 6A \& B) as well as activity (Fig. 6C) was increased significantly in cerebellum $(* * p 0.01)$ but remained unchanged in the cortex of ALF rats.

Level of NO:

Level of NO was found to be increased significantly in both brain regions of ALF rats indicating the induction of nitrosative stress, however, like nNOS, relatively higher in cerebellum (*** $p \leq 0.001$ ) than cortex $\left({ }^{*} p \leq 0.05\right)$ (Fig. 8A). 
cGMP level:

Level of cGMP was also found to be significantly increased in both cerebral cortex and cerebellum of ALF rats when compared to control rats (Fig. 8B), however, likewise nNOS and NO levels, more augmented in cerebellum ( $\left.{ }^{* \star} p \leq 0.001\right)$ than cortex ( $\left.{ }^{*} p \leq 0.01\right)$. Up regulation of both NO and cGMP level in both brain tissues suggested the activation of NMDAR mediated glutamate-NO-cGMP pathwayin ALF rats.

\section{Discussion}

Previous report from our group that ALF in rats activated glutamine-glutamate cycle to maintain physiological ammonia level but induced oxidative stress in cerebral cortex and cerebellum [28], led us to investigate whether and how this activation is associated with the induction of brain edema, NMDAR mediated glutamate-NO-cGMP pathway and nitrosative stress in ALF rats. For understanding this, we have used the TAA induced ALF rat model because it is widely accepted, mimicking the liver failure conditions similar to that of human patients and also suitable for the study of HE pathogenesis as recommended by International Society on Hepatic Encephalopathy and Nitrogen metabolism (ISHEN). As described previously [28] ALF in rats were induced by two intraperitoneal injection of $300 \mathrm{mg}$ TAA/kg b.w. for constitutively two days and the development of ALF was confirmed by the liver function test (LFT) and histopathological studies.

Elevated blood levels of sGOT and sGPT are widely serves as standard LFT markers to study the extent of the liver damage in the patients. In this study, we observed $\sim 11$-fold increase in sGOT level and $\nabla \sim 5$ foldincrease in SGPT levels in the TAA treated rats (Table 1). These values are very close to the previously reported levels recommended for fulminant hepatic failure [23, 28, 29] suggesting that these rats can be considered as a true ALF rodent model. This conclusion was further supported by the histopathological studies showing presence of large extent of hepatocyte necrosis in the central part of the liver sections of TAA treated rats (Fig. 1), such histopathological changes are reported to be associated with ALF rat model of acute type HE $[23,29]$. Moreover, 1.6 fold $\left({ }^{\star} p \leq 0.05\right)$ increase in serum ammonia concentration (Table 1) can be correlated well with the similar HA condition reported earlier for the ALF rats [28]. Together these findings suggested the establishment of true ALF with acute HA in present experimental rats and thus, can be used for exploring the cerebral changes occur at molecular level under ALF condition.

Broadly there are two ways by which increased ammonia concentration can affect brain functions; one, by causing hyper-osmolality in the brain cells and second, by deranging neurotransmission functions in specific brain regions. Glutamine-glutamate cycle, which is exclusively responsible for ammonia metabolism in brain, contributes centrally in the both above process. In the present study, though, blood ammonia level was found to be significantly increased (Table 1), static levels of ammonia and glutamate but increased glutamine concentration $\left({ }^{\star} p \leq 0.05\right)$ were observed in cerebral cortex and cerebellum of ALF rats (Table 2). Together these findings along with significantly increased glutamine synthetase (GS) and glutaminase (GA) enzymes activities (unpublished data) supported the earlier reports that ALF in rats 
activates the ammonia metabolism via activation of glutamine-glutamate cycle [28]. This is appeared to be an early defence mechanism of the brain to prevent acute ammonia toxicity, however, it may consequent to the cerebral dysfunction in the ALF patients $[9,30,31]$.

In order to identify the hyper-osmotic role of increased glutamine concentration in the development of brain edema, we have measured the brain water contents in ALF rats by wet/drying method [24] which was found to be significantly increased (Fig. 2) and thus suggesting the induction of cerebral edema. Since, we have not found the astrocytes swelling in haematoxylin and eosin histology of brain tissues (unpublished data), indicating that augmented glutamine concentration is not enough to induce the astrocytes swelling and thus, cytotoxic brain edema. Although, the mechanism of ammonia induced astrocytes swelling is still not clear, present findings are appeared to be not in agreement with the glutamine-osmolyte hypothesis, whereas supported those reports described that glutamine level is not directly corelated with the astrocytes swelling or degree of $\mathrm{HE}[31,32]$. It has been suggested that instead of absolute level, duration and persistent HA condition determine the brain glutamine level and its correlation with cerebral edema [33]. In present context, it is argued that increased glutamine concentration is an early event, however, astrocytes swelling may result when elevated glutamine concentration consistently present at later stage where other osmolyte such as alanine may also contribute in the swelling process [34]. Moreover, astrocytic changes such as Alzheimer's type II astrocytosis are more commonly observed during chronic HE than that of acute HE [35].

Although, we have not found the astrocytes swelling, increased water content in brain (Fig. 2) indicated the presence of vasogenic brain edema in the present ALF rat model. This has been described that HA increased the permeability of blood brain barrier (BBB) result into the net gain of water and plasma accumulated in the extracellular regions inducing vasogenic edema. Previously, it was considered that cytotoxic edema is only responsible for induction of brain edema due to not findings the structural damage in BBB in ALF condition [8,36]. However, it has been now well known that not only structural changes in BBB by alternation of tight junction elements like claudin- 5 and occludin, inflammatory cytokines such as TNFa directly or other factors released by liver damage such as matrix metalloproteinase, oxidative and nitrosative stress contribute indirectly in the pathogenesis of cerebral edema through vasogenic injury in the BBB integrity $[10,37]$. Taking in consideration of our previous report of oxidative stress in similar ALF rat model [28] from this present study, it is suggested that ALF in rats may induce the cerebral edema in form of vasogenic edema, interestingly even in the absence of cytotoxic edema where it can be inferred that increased concentration of glutamine was not sufficient enough to induce astrocytes swelling and cytotoxic edema.

The glutamine-glutamate cycle is also regulating the glutamate homeostasis in brain by preventing its excessive concentration to avoid excitotoxicity. Total glutamate concentration has mostly been reported to be decreased in the rats with acute HA or ALF [38-40], however, extracellular glutamate concentration as well as those of cerebral spinal fluid (CSF) has been observed to be increased in the brain exposed to ammonia and several ALF models [41, 42]. In the present study, though, we have found increased GS and GA activities, but constant glutamate concentrations in both cerebral cortex and cerebellum (Table 2).

Page $11 / 30$ 
Since we have estimated glutamate concentration in cytosolic fraction after brain homogenization, this reflects mainly the intracellular concentration of glutamate. In present context it has been suggested that not all glutamate released by neurons is recaptured by astrocytes for glutamine synthesis, some of them may lost because glutamate serve as the intermediate metabolite for other metabolic pathways such as synthesis of neurotransmitter GABA [43] and in the TCA cycle for maintaining the energy balance due to depletion of ATP concentration occurred in glutamine synthesis $[43,44]$. Moreover, since the de novo synthesis of glutamate and GABA does not take place in the neurons from glucose due to lack of the necessary enzymes, glutamine provides the carbon source for repletion of both glutamate and GABA. It has been demonstrated that $80 \%$ of total glutamine synthesis occur for this repletion pathway where astrocytes serve as a glutamine pool. This may be one reasons of increased glutamine concentration in astrocytes without it's swelling. Thus, the present findings suggested that that activation of glutamateglutamine cycle is an adoptive response in both cerebral cortex and cerebellum against HA during ALF condition where physiological level of ammonia and glutamate were maintained and increased glutamine was served as a precursor for several anabolic pathways. However, presence of vasogenic edema raised a question to investigate the connection between glutamine-glutamate cycle activation and pathogenesis of ALF induced cerebral dysfunction. Therefore, it will be now important to see the effects of glutamine-glutamate activation on the NMDAR mediated glutamate-NO-cGMP signalling.

Studies reported that over activation of glutamate receptor like NMDAR in brain tissues induced death in rats with ALF or acute HA which may be prevented by several antagonists $[4,45,46]$. However, complete blocking of NMDAR has shown adverse effects and suggested to be poor therapeutic target for several excitotoxic diseases such as brain ischemia and epilepsy as well as HE [47]. It is noteworthy that NMDAR have different subtypes which confer the unique function and distributed heterogeneously in brain tissues. Therefore, understanding the molecular mechanism of regulation of different NMDAR subtypes is now offer to develop more effective and clinically useful drugs. In the present study, NR2A-2D subunits genes were found to be differentially regulated in the cerebral cortex and cerebellum of ALF rats. In cortex, except constant NR-2B (Fig. 3C \& D), others three subunits, NR2A, 2C and 2D were decreased significantly (Fig. 3A \& B, 4A-D), however, in cerebellum NR2A, 2B and 2C (Fig. 3A-D \& 4A \& B) were remain unchanged but NR2D increased significantly (Fig. 4B \& D). It has been described that NR2A-containing NMDAR promotes neuroprotective action, however, NR2B-containing NMDAR activation caused excitotoxicity and neuronal damage after acute brain injuries such as stroke and trauma [48]. In present context, unchanged expression of NR2B gene in both tissues indicated the absence of excitotoxicity or activation of neuronal damage pathway. However, down regulation of NR2A gene suggested suppression of neuroprotective pathway in cortex but not in cerebellum where static NR2A gene was found. On the other hand, NMDAR with NR2C/2D are known to be contributed about $40 \%$ of total NMDAR response in brain regions wherever they are expressed and could permit selective modification of NMDAR signalling due to lower sensitivity for Mg2+ blocking and slower deactivation kinetics [49,50]. In present findings, significantly decreased expression of both NR2C and NR2D (Fig. 4A-D) in cortex of ALF rats suggested suppression of NMDAR response, however, constant NR2C with significantly increased expression of NR2D gene suggested activation of NMDAR signalling in the cerebellum (Fig. 4A-D). Since the NR2D has the highest 
potency for glutamate, a small amount or even short duration of glutamate binding on NMDAR containing NR2D subunits may evoke the more potent NMDAR response. In present context, though, we have found the constant glutamate concentration in both cortex and cerebellum, prolong duration of glutamate-glutamine cycle activation may be responsible for the brain region specific up regulation of NR2D containing NMDAR. As per our knowledge, though activation of NR2B or NR2A subunits in brain tissues were reported in liver diseases [3,7], no study was found regarding role of NR2C/2D genes in the pathogenesis of $\mathrm{HE} /$ death due to acute and/or chronic liver failure; while, activation of NR2D gene was found to be implicated in the Alzymer diseases and which has been demonstrated to be ameliorated by NR2D antagonist [51, 52]. Together these finding of differential expression NR2A-D subunits indicated that activation of glutamine-glutamate cycle affects NMDAR regulation differentially in cerebral cortex and cerebellum where cortex showed suppression, however, cerebellum showed relatively activation of NMDAR response in ALF rats.

Being an ion channel, NMDAR exert their effects by $\mathrm{Ca} 2+$ influx in to the post synaptic neurons that led the activation of $\mathrm{Ca} 2+$ dependent enzymes such as NOS which in turn activate the NO signalling pathway at down steam level. A threshold level of NO is required for activation glutamate-NO-cGMP pathway involved in higher order brain function such as learning and memory; however, augmented production of NO is known to be induced the neuropathological pathway including nitrosative stress, excitotoxicity and neuronal cell death. In present study, we have found the significantly increased level of NO in blood serum (Table $1,{ }^{\star \star} p \leq 0.01$ ) as well as in both brain tissues (Fig. $8 \mathrm{~A}$ ) suggested induction of nitrosative stress in brain of ALF rats. However, significantly greater increased level in cerebellum ( $\left.{ }^{\star \star \star} p \leq 0.001\right)$ than cortex $\left({ }^{\star} p \leq 0.05\right)$ (Fig. 8A) indicated the differential regulation of NOS isoforms in these brain tissues due to ALF. Moreover, NO produced by three NOS isoforms are distributed heterogeneously and account for unique function in different brain regions [20].

Out of three NOS isoforms, nNOS is mainly express in neuronal cells and structurally connected with NR2 subunits via an adaptor protein called post synaptic density protein-95 (PSD-95) [53]. This is reported that activation of NMDAR is directly coupled with NO production by nNOS and therefore it is speculated that nNOS mainly transmit the NMDAR mediated NO signalling pathway and may be modulated differentially in different brain regions during neuropathology of ALF/HE [54]. In present study, expression of nNOS gene (Fig. 5A \& B) as well as protein levels (Fig. 5C \& D) were found to be increased significantly in both brain tissues, however, it was more prominent in cerebellum than cortex. This may be due to the activating patterns of NMDAR containing NR2A-D subunits in cerebellum to that of suppressing trends in the cortex of ALF rats (Fig. $3 \& 4$ ).

The NO synthesized by eNOS in endothelial cells is act as vasodilator and maintains vascular homeostasis. Information regarding role of eNOS in ALF induced death is not clear. However, increased NO production by eNOS is considered to be responsible for high cerebral blood flow, increased delivery of ammonia to the brain and edema. Previously it has been reported that high expression of eNOS can induce vasogenic brain edema by disrupting the BBB in epilepsy rat model [55]. Increased expression of eNOS mRNA in cerebral cortex was also reported in ALF rats, however, eNOS did not correlate well with 
$\mathrm{HE} /$ edema grade in the early stages of $\operatorname{ALF}[4,56]$. In the present study, eNOS gene was significantly increased only in the cortex, however, remain constant in cerebellum (Fig. 7). This suggested that eNOS may be contributed in the induction of vasogenic edema in cortex.

The NO produced by iNOS is mainly participated in neuro-inflammatory and neuropathological pathway and considered to be responsible for enhancing the NO level. In present study, iNOS gene as well as iNOS activity were observed to be increased significantly in cerebellum but remain constant in the cortex (Fig. 6). This differential regulation of iNOS may be responsible for significantly more increased level of NO in cerebellum than cortex.

Together these finding of different NOS isoforms indicated the activation of NO/NOS axis in both tissues, however, with greater intensity in the cerebellum than cortex of ALF rats. This differential regulation of NO/NOS axis is looking in agreement with the down regulation of most NR2 subunits in cortex whereas activating pattern of NR2 subunits (NR2D) in cerebellum.

Production cGMP is the ultimate result of NMDAR mediated NO signalling. Significantly increased level of cGMP in both brain regions (Fig. 8B) suggested activation of NO signalling in both brain tissues, however, again in the support with the trend of more intense in cerebellum than cortex of ALF rats.

Based on the present findings it is summarized that ALF in rats activates glutamate-glutamine cycle to metabolise elevated ammonia level in the brain tissue. However, this activation modulates the NR2A-D subunits containing NMDAR differentially in cerebral cortex and cerebellum of ALF rats. Cerebral cortex showed down regulation of NR2A, 2 C and 2D subunits containing NMDAR, however cerebellum showed constant pattern of NR2A-C genes but up regulation of NR2D subunit containing NMDAR. This is followed by the induction of NOS/NO-cGMP signalling in both brain tissues. However, cerebellum showed significantly greater up-regulation of nNOS and iNOS followed by NO production than cortex indicated induction of greater nitrosative stress in cerebellum than cortex. Similarly, significant increase in cGMP level in both brain regions indicated the induction of glutamate-NO-cGMP pathway in ALF rats but more prominent in cerebellum than cortex. Moreover, significantly increased glutamine level is not associated with astrocyte swelling. However, increased brain water content suggested the induction of vasogenic edema in ALF rats. Our previous report of induced oxidative stress (28) and presently upregulation of eNOS in cerebral cortex along with nitrosative stress in both brain tissues are suggested to be contributed in the process of induction of vasogenic edema in ALF rats.

Thus, it can be concluded that ALF in rats induced vasogenic edema without the presence of cytotoxic edema and NOS-NO-cGMP pathway after differential modulation of NMDAR in cerebral cortex and cerebellum where cerebellum is looking more sensitive than cortex against ALF induced such cerebral derangements. It is suggested that selective NOS inhibitors can be better option than un-physiological blocking of NMDAR for the treatment of ALF patients.

\section{Declarations}


Acknowledgement: A special acknowledgement to Prof. Surendra Kumar Trigun, Dept. of Zoology, BHU for providing lab facility for RT-PCR and western blotting.

Fundings: This work was financially supported by DST-SERB Young Scientist start-up grant (File No: YSS/2014/000073) and UGC start-up grant to Dr. Santosh Singh.

Competing interests: There is no any conflict of interest among authors.

Authors contributions: SS designed the experiments; DJ and AM performed the experiment; SS and AM analysed the data and wrote the paper.

Data availability: All data used in present study are mentioned in the manuscript.

Ethics approval: The use of animal in present study was approved by the institutional animal ethical committee (IAEC), Guru Ghasidas Vishwavidyalaya, Bilaspur, C.G., India (Ref. No.

994/GO/ERe/S/06/CPCSEA).

\section{Consent to participate: NA}

Consent to publish: All authors are agreed for publication.

\section{References}

1. Toma D., Lazar O., Bontas E. (2020) Acute Liver Failure. In: Radu-lonita F., Pyrsopoulos N., Jinga M., Tintoiu I., Sun Z., Bontas E., (eds) Liver Diseases. Springer, Cham. https://doi.org/10.1007/978-3-03024432-3_32

2. Bernal, W., Lee, W. M., Wendon, J., Larsen, F. S., \& Williams, R (2015) Acute liver failure: A curable disease by 2024. Journal of hepatology. 62(1 Suppl), S112-S120. https://doi.org/10.1016/j.jhep.2014.12.016

3. Bernal W, Auzinger G, Dhawan A, Wendon J (2010) Acute liver failure. Lancet; 376:190-201.

4. Omar Cauli, Regina Rodrigo, Jordi Boix, Blanca Piedrafita, Ana Agusti, and Vicente Felipo (2008) Acute liver failure-induced death of rats is delayed or prevented by blocking NMDA receptors in brain. Am J Physiol Gastrointest Liver Physiol. 295: G503-G511.

5. Helene Gilgenkrantz and Alexandra Collin de l'Hortety (2018) Understanding Liver Regeneration From Mechanisms to Regenerative Medicine. The American Journal of Pathology; Vol. 188, No. 6,

6. Naofumi Nagasue et. al. (1987) Human Liver Regeneration after Major Hepatic Resection A Study of Normal Liver and Livers with Chronic Hepatitis and Cirrhosis. Ann. Surg.; VOL. 206, NO. I

7. Cauli, O., López-Larrubia, P., Rodrigo, R., Agusti, A., Boix, J., Nieto-Charques, L., Cerdán, S., \& Felipo, V (2011) Brain region-selective mechanisms contribute to the progression of cerebral alterations in acute liver failure in rats. Gastroenterology, 140(2), 638-645.

https://doi.org/10.1053/j.gastro.2010.10.043 
8. Vaquero J, Butterworth RF (2008) Mechanisms of brain edema in acute liver failure and impact of novel therapeutic interventions. Neurol Res; 29: 683-690.

9. Felipo V, Butterworth RF (2002) Neurobiology of ammonia. Prog Neurobiol; 67:259-279

10. Kato M, Sugihara J, Nakamura T et al. (1989) Electron microscopic study of the blood-brain barrier in rats with brain edema and encephalopathy due to acute hepatic failure. Gastroenterol Jpn; 24:135142.

11. Warren, K.S., Schenker, S (1964) Effect of an inhibitor of glutamine synthesis (methionine sulfoximine) on ammonia toxicity and metabolism. J. Lab. Clin. Med; 64, 442-449.

12. Reddy, P. V., Rao, K. V., \& Norenberg, M. D. (2008). The mitochondrial permeability transition, and oxidative and nitrosative stress in the mechanism of copper toxicity in cultured neurons and astrocytes. Laboratory investigation; a journal of technical methods and pathology, 88(8), 816-830. https://doi.org/10.1038/labinvest.2008.49

13. Trey C, Davidson CS (1970) The management of fulminant hepatic failure. Prog Liver Dis; 3:282298.

14. Liu L, Wong TP, Pozza MF, et al. (2004) Role of NMDA receptor subtypes in governing the direction of hippocampal synaptic plasticity. Science.;304(5673):1021-1024. doi:10.1126/science.1096615

15. Massey PV, Johnson BE, Moult PR et al. (2004) Differential roles of NR2A and NR2B-containing NMDA receptors in cortical long-term potentiation and long-term depression. J Neurosci;24(36):78217828. doi:10.1523/JNEUROSCI.1697-04.2004

16. Kasper B. Hansen, Feng Yi, Riley E. Perszyk, Hiro Furukawa, Lonnie P. Wollmuth, Alasdair J. Gibb, Stephen F. Traynelis (2018) Structure, function, and allosteric modulation of NMDA receptors. J Gen Physio/ 6; 150 (8): 1081-1105. doi: https://doi.org/10.1085/jgp.201812032

17. Flores-Soto, M. E., Chaparro-Huerta, V., Escoto-Delgadillo, M., Vazquez-Valls, E., González-Castañeda, R. E., \& Beas-Zarate, C. (2012). Estructura y función de las subunidades del receptor a glutamato tipo NMDA [Structure and function of NMDA-type glutamate receptor subunits]. Neurologia (Barcelona, Spain), 27(5), 301-310. https://doi.org/10.1016/j.nrl.2011.10.014

18. Singh, S., \& Trigun, S. K. (2010). Activation of neuronal nitric oxide synthase in cerebellum of chronic hepatic encephalopathy rats is associated with up-regulation of NADPH-producing pathway. Cerebellum (London, England), 9(3), 384-397. https://doi.org/10.1007/s12311-010-0172-y

19. Prast, H., \& Philippu, A. (2001). Nitric oxide as modulator of neuronal function. Progress in neurobiology, 64(1), 51-68. https://doi.org/10.1016/s0301-0082(00)00044-7

20. Guix, F. X., Uribesalgo, I., Coma, M., \& Muñoz, F. J. (2005). The physiology and pathophysiology of nitric oxide in the brain. Progress in neurobiology, 76(2), 126-152. https://doi.org/10.1016/j.pneurobio.2005.06.001

21. Kong, T., Choi, J. K., Park, H., Choi, B. H., Snyder, B. J., Bukhari, S., Kim, N. K., Huang, X., Park, S. R., Park, H. C., \& Ha, Y. (2009). Reduction in programmed cell death and improvement in functional outcome of transient focal cerebral ischemia after administration of granulocyte-macrophage 
colony-stimulating factor in rats. Laboratory investigation. Journal of neurosurgery, 111(1), 155163. https://doi.org/10.3171/2008.12.JNS08172

22. Terpolilli, N. A., Zweckberger, K., Trabold, R., Schilling, L., Schinzel, R., Tegtmeier, F., \& Plesnila, N. (2009). The novel nitric oxide synthase inhibitor 4-amino-tetrahydro-L-biopterine prevents brain edema formation and intracranial hypertension following traumatic brain injury in mice. Journal of neurotrauma, 26(11), 1963-1975. https://doi.org/10.1089/neu.2008.0853

23. Sathyasaikumar, K. V., Swapna, I., Reddy, P. V., Murthy, C., Dutta Gupta, A., Senthilkumaran, B., \& Reddanna, P. (2007). Fulminant hepatic failure in rats induces oxidative stress differentially in cerebral cortex, cerebellum and pons medulla. Neurochemical research, 32(3), 517-524. https://doi.org/10.1007/s11064-006-9265-x

24. Tamaoki, S., Suzuki, H., Okada, M., Fukui, N., Isobe, M., \& Saito, T. (2016). Development of an experimental rat model of hyperammonemic encephalopathy and evaluation of the effects of rifaximin. European journal of pharmacology, 779, 168-176.

https://doi.org/10.1016/j.ejphar.2016.03.024

25. Stuehr, D. J., Cho, H. J., Kwon, N. S., Weise, M. F., \& Nathan, C. F. (1991). Purification and characterization of the cytokine-induced macrophage nitric oxide synthase: an FAD- and FMNcontaining flavoprotein. Proceedings of the National Academy of Sciences of the United States of America, 88(17), 7773-7777. https://doi.org/10.1073/pnas.88.17.7773

26. Sambrook, J. and Russell, D.W. (2001) Molecular cloning: a laboratory manual. Vol. 2, 3rd edn. Cold Spring Harbor Laboratory Press, New York.

27. Laemmli U. K. (1970). Cleavage of structural proteins during the assembly of the head of bacteriophage T4. Nature, 227(5259), 680-685. https://doi.org/10.1038/227680a0

28. Singh S, Mondal P, Trigun SK (2014) Acute Liver Failure in Rats Activates Glutamine-Glutamate Cycle but Declines Antioxidant Enzymes to Induce Oxidative Stress in Cerebral Cortex and Cerebellum. PLoS ONE 9(4): e95855. doi:10.1371/journal.pone.0095855

29. Shapiro, H., Ashkenazi, M., Weizman, N., Shahmurov, M., Aeed, H., \& Bruck, R. (2006). Curcumin ameliorates acute thioacetamide-induced hepatotoxicity. Journal of gastroenterology and hepatology, 21(2), 358-366. https://doi.org/10.1111/j.1440-1746.2005.03984.x

30. Murthy CRK, Rama Rao KV, Bai G et. al, Ammonia induced production of free radicals in primary culture of rat astrocytes. J Neurosci Res (2001); 66:282-288

31. Albrecht, J., Zielińska, M., \& Norenberg, M. D. (2010). Glutamine as a mediator of ammonia neurotoxicity: A critical appraisal. Biochemical pharmacology, 80(9), 1303-1308. https://doi.org/10.1016/j.bcp.2010.07.024

32. Jayakumar, A. R., Rao, K. V., Murthy, C., \& Norenberg, M. D. (2006). Glutamine in the mechanism of ammonia-induced astrocyte swelling. Neurochemistry international, 48(6-7), 623-628. https://doi.org/10.1016/j.neuint.2005.11.017

33. Takahashi, H., Koehler, R. C., Brusilow, S. W., \& Traystman, R. J. (1991). Inhibition of brain glutamine accumulation prevents cerebral edema in hyperammonemic rats. The American journal of 
physiology, 261(3 Pt 2), H825-H829. https://doi.org/10.1152/ajpheart.1991.261.3.H825

34. Vaquero, J., Chung, C., \& Blei, A. T. (2003). Brain edema in acute liver failure. A window to the pathogenesis of hepatic encephalopathy. Annals of hepatology, 2(1), 12-22.

35. Norenberg M. D. (1987). The role of astrocytes in hepatic encephalopathy. Neurochemical pathology, 6(1-2), 13-33. https://doi.org/10.1007/BF02833599

36. Nguyen J. H. (2012). Blood-brain barrier in acute liver failure. Neurochemistry international, 60(7), 676-683. https://doi.org/10.1016/j.neuint.2011.10.012

37. Lehner, C., Gehwolf, R., Tempfer, H., Krizbai, I., Hennig, B., Bauer, H. C., \& Bauer, H. (2011). Oxidative stress and blood-brain barrier dysfunction under particular consideration of matrix metalloproteinases. Antioxidants \& redox signaling, 15(5), 1305-1323. https://doi.org/10.1089/ars.2011.3923

38. Bosman D. K., Deutz N. E., De Graaf A. A., vd Hulst R. W., Van Eijk H. M., Bovee W. M., Maas M. A., Jorning G. G. and Chamuleau R. A. (1990) Changes in brain metabolism during hyperammonemia and acute liver failure: results of a comparative $1 \mathrm{H}-\mathrm{NMR}$ spectroscopyand biochemical investigation. Hepatology 12, 281-290.

39. Swain M. S., Bergeron M., Audet R., Blei A. T. and Butterworth R. F. (1992b) Monitoring of neurotransmitter amino acids by means of an indwelling cisterna magna catheter: a comparison of two rodent models of fulminant liver failure. Hepatology 16, 1028-1035.

40. Hilgier W. and Olson J. E. (1994) Brain ion and amino acid contents during edema development in hepatic encephalopathy. J. Neurochem. 62, 197-204.

41. de Knegt, R. J., Gramsbergen, J. B., \& Schalm, S. W. (1994). 45CaCl2 autoradiography in brain from rabbits with encephalopathy from acute liver failure or acute hyperammonemia. Metabolic brain disease, 9(2), 153-160. https://doi.org/10.1007/BF01999768

42. Vaquero, J., \& Butterworth, R. F. (2006). The brain glutamate system in liver failure. Journal of neurochemistry, 98(3), 661-669. https://doi.org/10.1111/j.1471-4159.2006.03918.x

43. Schousboe, A., Scafidi, S., Bak, L. K., Waagepetersen, H. S., \& McKenna, M. C. (2014). Glutamate metabolism in the brain focusing on astrocytes. In: V. Parpura et al. (eds.) Advances in neurobiology, 11, 13-30. https://doi.org/10.1007/978-3-319-08894-5_2

44. Schousboe, A., Bak, L. K., \& Waagepetersen, H. S. (2013). Astrocytic Control of Biosynthesis and Turnover of the Neurotransmitters Glutamate and GABA. Frontiers in endocrinology, 4, 102. https://doi.org/10.3389/fendo.2013.00102

45. Kosenko, E., Kaminski, Y., Lopata, O., Muravyov, N., \& Felipo, V. (1999). Blocking NMDA receptors prevents the oxidative stress induced by acute ammonia intoxication. Free radical biology \& medicine, 26(11-12), 1369-1374. https://doi.org/10.1016/s0891-5849(98)00339-6

46. Rosenmund, C., Feltz, A., \& Westbrook, G. L. (1995). Calcium-dependent inactivation of synaptic NMDA receptors in hippocampal neurons. Journal of neurophysiology, 73(1), 427-430. https://doi.org/10.1152/jn.1995.73.1.427 
47. Mondal, P., \& Trigun, S. K. (2015). Bacopa monnieri Extract (CDRI-08) Modulates the NMDA Receptor Subunits and nNOS-Apoptosis Axis in Cerebellum of Hepatic Encephalopathy Rats. Evidence-based complementary and alternative medicine: eCAM, 2015, 535013.

https://doi.org/10.1155/2015/535013

48. Liu, Y., Wong, T. P., Aarts, M., Rooyakkers, A., Liu, L., Lai, T. W., Wu, D. C., Lu, J., Tymianski, M., Craig, A. M., \& Wang, Y. T. (2007). NMDA receptor subunits have differential roles in mediating excitotoxic neuronal death both in vitro and in vivo. The Journal of neuroscience : the official journal of the Society for Neuroscience, 27(11), 2846-2857. https://doi.org/10.1523/JNEUROSCI.0116-07.2007

49. Hansen, K. B., Yi, F., Perszyk, R. E., Furukawa, H., Wollmuth, L. P., Gibb, A. J., \& Traynelis, S. F. (2018). Structure, function, and allosteric modulation of NMDA receptors. The Journal of general physiology, 150(8), 1081-1105. https://doi.org/10.1085/jgp.201812032

50. Akazawa, C., Shigemoto, R., Bessho, Y., Nakanishi, S., \& Mizuno, N. (1994). Differential expression of five N-methyl-D-aspartate receptor subunit mRNAs in the cerebellum of developing and adult rats. The Journal of comparative neurology, 347(1), 150-160. https://doi.org/10.1002/cne.903470112

51. Liu, J., Chang, L., Song, Y., Li, H., \& Wu, Y. (2019). The Role of NMDA Receptors in Alzheimer's Disease. Frontiers in neuroscience, 13, 43. https://doi.org/10.3389/fnins.2019.00043

52. Mullasseril, P., Hansen, K. B., Vance, K. M., Ogden, K. K., Yuan, H., Kurtkaya, N. L., Santangelo, R., Orr, A. G., Le, P., Vellano, K. M., Liotta, D. C., \& Traynelis, S. F. (2010). A subunit-selective potentiator of NR2C- and NR2D-containing NMDA receptors. Nature communications, 1, 90. https://doi.org/10.1038/ncomms1085

53. Lim, Indra \& Merrill, Michelle \& Chen, Yucui \& Hell, Johannes. (2003). Disruption of the NMDA receptor-PSD-95 interaction in hippocampal neurons with no obvious physiological short-term effect. Neuropharmacology. 45. 738-54. 10.1016/S0028-3908(03)00276-4.

54. Kourosh-Arami, M., Hosseini, N., Mohsenzadegan, M., Komaki, A. \& Joghataei, M. (2020). Neurophysiologic implications of neuronal nitric oxide synthase. Reviews in the Neurosciences, 31(6), 617-636. https://doi.org/10.1515/revneuro-2019-0111

55. Ko, A. R., Kim, J. Y., Hyun, H. W., \& Kim, J. E. (2015). Endothelial NOS activation induces the bloodbrain barrier disruption via ER stress following status epilepticus. Brain research, 1622, 163-173. https://doi.org/10.1016/j.brainres.2015.06.020

56. Milewski, K., Czarnecka, A. M., Albrecht, J., \& Zielińska, M. (2021). Decreased Expression and Uncoupling of Endothelial Nitric Oxide Synthase in the Cerebral Cortex of Rats with ThioacetamideInduced Acute Liver Failure. International journal of molecular sciences, 22(13), 6662. https://doi.org/10.3390/ijms22136662

\section{Tables}

\section{Methodology Tables:}

\section{Table A: Reagents of first strand cDNA synthesis}




\begin{tabular}{|ll|}
\hline Starting reaction mixture & $12 \mu \mathrm{l}$ \\
$5 \mathrm{X}$ reaction buffer & $4 \mu \mathrm{l}$ \\
\hline RiboLock ${ }^{\mathrm{TM}}$ RNase inhibitor & $1 \mu \mathrm{l}(20$ units) \\
\hline $10 \mathrm{mM}$ dNTP mix & $2 \mu \mathrm{l}$ \\
\hline RevertAid $^{\mathrm{TM}}$ M.MulV reverse transcriptase & $1 \mu \mathrm{l}(200$ units $)$ \\
\hline Total Volume & $20 \mu \mathrm{l}$ \\
\hline
\end{tabular}

Table B: The PCR reaction mixture

\begin{tabular}{|ll|}
\hline 10X PCR reaction buffer & $2.5 \mu \mathrm{l}$ \\
\hline $10 \mathrm{mM}$ dNTP mix & $0.5 \mu \mathrm{l}$ \\
\hline $10 \mathrm{pm} / \mu \mathrm{l}$ forward primer & $0.5 \mu \mathrm{l}$ \\
\hline $10 \mathrm{pm} / \mu \mathrm{l}$ reverse primer & $0.5 \mu \mathrm{l}$ \\
\hline Taq Polymerase $(1$ unit $)$ & $0.25 \mu \mathrm{l}$ \\
\hline CDNA & $2 \mu \mathrm{l}$ \\
\hline DEPC treated water & $18.75 \mu \mathrm{l}$ \\
\hline Total volume & $25 \mu \mathrm{l}$ \\
\hline
\end{tabular}

Table C: The PCR condition and primers 


\begin{tabular}{|c|c|c|c|c|c|}
\hline Genes & Primer sequence & PCR condition & & $\begin{array}{l}\text { No. of } \\
\text { cycle }\end{array}$ & $\begin{array}{l}\text { Amplificatio } \\
\text { n products } \\
\text { (bp) }\end{array}$ \\
\hline$\beta$-actin & $\begin{array}{l}\text { B-actin -LP } \\
\text { AAACTGGAACGGTGAAGGTG } \\
\text { B-actin -RP } \\
\text { AGAGAAGTGGGGTGGCTTTT }\end{array}$ & $\begin{array}{l}94^{\prime \prime} \mathrm{C}-1^{\prime} \\
94^{\circ} \mathrm{C}-30^{\prime \prime} \\
52^{\circ} \mathrm{C}-30^{\prime \prime} \\
72^{\circ} \mathrm{C}-30^{\prime \prime} \\
72^{\circ} \mathrm{C}-5^{\prime \prime}\end{array}$ & $29 \mathrm{x}$ & 30 & 368 \\
\hline $\mathrm{NR} 2 \mathrm{~A}$ & $\begin{array}{l}\text { NR2A-LP } \\
\text { ACATTGCAGAAGCTGCCTTT } \\
\text { NR2A-RP } \\
\text { TTCTGTGACCAGTCCTGCTG }\end{array}$ & $\begin{array}{l}94^{\prime \prime} \mathrm{C}-1^{\prime \prime} \\
94^{\circ} \mathrm{C}-30^{\prime \prime} \\
54^{\circ} \mathrm{C}-30^{\prime \prime} \\
72^{\circ} \mathrm{C}-30^{\prime \prime} \\
72^{\circ} \mathrm{C}-5^{\prime}\end{array}$ & $24 \mathrm{x}$ & 25 & 246 \\
\hline NR2B & $\begin{array}{l}\text { NR2B-LP } \\
\text { GGATCTACCAGTCTAACATG } \\
\text { NR2B-RP } \\
\text { GATAGTTAGTGATCCCACTG }\end{array}$ & $\begin{array}{l}94^{\prime \prime} \mathrm{C}-1^{\prime \prime} \\
94^{\circ} \mathrm{C}-30^{\prime \prime} \\
54^{\circ} \mathrm{C}-30^{\prime \prime} \\
72^{\circ} \mathrm{C}-30^{\prime \prime} \\
72^{\circ} \mathrm{C}-5^{\prime}\end{array}$ & $24 \mathrm{x}$ & 25 & 563 \\
\hline $\mathrm{NR} 2 \mathrm{C}$ & $\begin{array}{l}\text { NR2C-LP } \\
\text { TTGAGGACAACGTGGACACC } \\
\text { NR2C-RP } \\
\text { TCCAGTCGTATTCCTCCAGC }\end{array}$ & $\begin{array}{l}94^{\prime \prime} \mathrm{C}-1^{\prime} \\
94^{\circ} \mathrm{C}-30^{\prime \prime} \\
54^{\circ} \mathrm{C}-30^{\prime \prime} \\
72^{\circ} \mathrm{C}-30^{\prime \prime} \\
72^{\circ} \mathrm{C}-5^{\prime} \\
\end{array}$ & $29 \mathrm{x}$ & 30 & 576 \\
\hline NR2D & $\begin{array}{l}\text { NR2D-LP } \\
\text { GCACTTGCATCAGAGACTCG } \\
\text { NR2D-RP } \\
\text { CTCACCAATCATGCCATTCC }\end{array}$ & $\begin{array}{l}94^{\prime \prime} \mathrm{C}-1^{\prime \prime} \\
94^{\circ} \mathrm{C}-30^{\prime \prime} \\
54^{\circ} \mathrm{C}-30^{\prime \prime} \\
72^{\circ} \mathrm{C}-30^{\prime \prime} \\
72^{\circ} \mathrm{C}-5^{\prime}\end{array}$ & $29 \mathrm{x}$ & 30 & 546 \\
\hline nNOS & $\begin{array}{l}\text { nNOS-LP } \\
\text { AGCACCTTTGGCAATGGAGA } \\
\text { nNOS-RP } \\
\text { ATCACAGGCTGCCTTGAAGA }\end{array}$ & $\begin{array}{l}94^{\prime \prime} \mathrm{C}-1^{\prime \prime} \\
94^{\circ} \mathrm{C}-30^{\prime \prime} \\
52^{\circ} \mathrm{C}-30^{\prime \prime} \\
72^{\circ} \mathrm{C}-30^{\prime \prime}- \\
72^{\circ} \mathrm{C}-5^{\prime}\end{array}$ & $29 x$ & 30 & 402 \\
\hline iNOS & $\begin{array}{l}\text { iNOS-LP } \\
\text { GCAGAATGTGACCATCATGGAC } \\
\text { C } \\
\text { iNOS-RP } \\
\text { AAGGACTCTGAGGCTGTGTGG }\end{array}$ & $\begin{array}{l}94^{10} \mathrm{C}-1^{\prime \prime} \\
94^{\circ} \mathrm{C}-30^{\prime \prime} \\
54^{\circ} \mathrm{C}-30^{\prime \prime} \\
72^{\circ} \mathrm{C}-30^{\prime \prime} \\
72^{\circ} \mathrm{C}-5^{\prime \prime}\end{array}$ & $29 \mathrm{x}$ & 30 & 246 \\
\hline eNOS & $\begin{array}{l}\text { eNOS-LP } \\
\text { CCTTCCGCTGCCACCTGATCC } \\
\text { T } \\
\text { eNOS-RP } \\
\text { AACATGTGTCCTTGCTCGAGGC } \\
\text { A }\end{array}$ & $\begin{array}{l}94^{\prime \prime} \mathrm{C}-1^{\prime \prime} \\
94^{\circ} \mathrm{C}-30^{\prime \prime} \\
56^{\circ} \mathrm{C}-30^{\prime \prime} \\
72^{\circ} \mathrm{C}-30^{\prime \prime} \\
72^{\circ} \mathrm{C}-5^{\prime}\end{array}$ & $29 \mathrm{x}$ & 30 & 343 \\
\hline
\end{tabular}

Table D: Details of antibodies processing against different proteins

\begin{tabular}{|llllllll|}
\hline $\begin{array}{l}\text { S. } \\
\text { No. }\end{array}$ & Proteins & MW (kDa) & Gel \% & Primary Ab & Dilution & Secondary Ab & Dilution \\
\hline 1 & nNOS & 160 & 6 & Rabbit polyclonal & $1: 4000$ & Anti-rabbit & $1: 8000$ \\
& & & & & & HRP conjugate & \\
2 & B-actin & 42 & 12 & $\begin{array}{l}\text { Mouse } \\
\text { Monoclonal } \\
\text { peroxidase }\end{array}$ & & & \\
& & & & & \\
\end{tabular}


Table-1. Effect of ALF in biological parameters of Serum

\begin{tabular}{|llll|}
\hline S. NO. & Parameters & Control Rats & ALF Rats \\
\hline 1. & Alanine amino transferase $(\mathrm{IU} / \mathrm{L})$ sGOT & $610 \pm 25$ & $6700 \pm 33 * \star$ \\
\hline 2. & Aspartate amino transferase $(\mathrm{IU} / \mathrm{L})$ sGPT & $1040 \pm 67$ & $4090 \pm 79 * \star$ \\
\hline 3. & Ammonia $(\mu \mathrm{mol} / \mathrm{ml})$ & $0.32 \pm 0.03$ & $0.51 \pm 0.05^{\star}$ \\
\hline 4. & Nitric oxide $(\mu \mathrm{mol} / \mathrm{ml})$ & $20.63 \pm 1.76$ & $50.05 \pm 2.09 \star \star$ \\
\hline
\end{tabular}

values are mean \pm SD where $n=4$ and each experiment done in duplicates. ${ }^{*} p<0.05, * \star p<0.01$ (control verses experimental group)

Table-2. Effect of ALF in brain ammonia, glutamine and glutamate level

\begin{tabular}{|llll|}
\hline Parameters & Brain tissues & Control Rats & ALF Rats \\
\hline Cerebral cortex & Glutamate level $(\mu \mathrm{mol} / \mathrm{g}$ wet wt) & $2.57 \pm 0.16$ & $2.98 \pm 0.12$ \\
\cline { 2 - 4 } & Glutamine level $(\mathrm{mmol} / \mathrm{g}$ wet $\mathrm{wt})$ & $4.27 \pm 0.25$ & $8.47 \pm 0.75^{\star}$ \\
\cline { 2 - 4 } & Ammonia level $(\mathrm{mM} / \mathrm{g}$ wet $\mathrm{wt})$ & $1.32 \pm 0.07$ & $1.45 \pm 0.04$ \\
\hline Cerebellum & Glutamate level $(\mu \mathrm{mol} / \mathrm{g}$ wet $\mathrm{wt})$ & $2.21 \pm 0.08$ & $2.79 \pm 0.05$ \\
\cline { 2 - 4 } & Glutamine level $(\mathrm{mmol} / \mathrm{g}$ wet $\mathrm{wt})$ & $4.67 \pm 0.25$ & $9.27 \pm 1.12^{\star}$ \\
\cline { 2 - 4 } & Ammonia level $(\mathrm{mM} / \mathrm{g}$ wet wt) & $1.53 \pm 0.14$ & $1.71 \pm 0.08$ \\
\hline
\end{tabular}

values are mean $\pm S D$ where $n=4$ and each experiment done in duplicates.

\section{Figures}



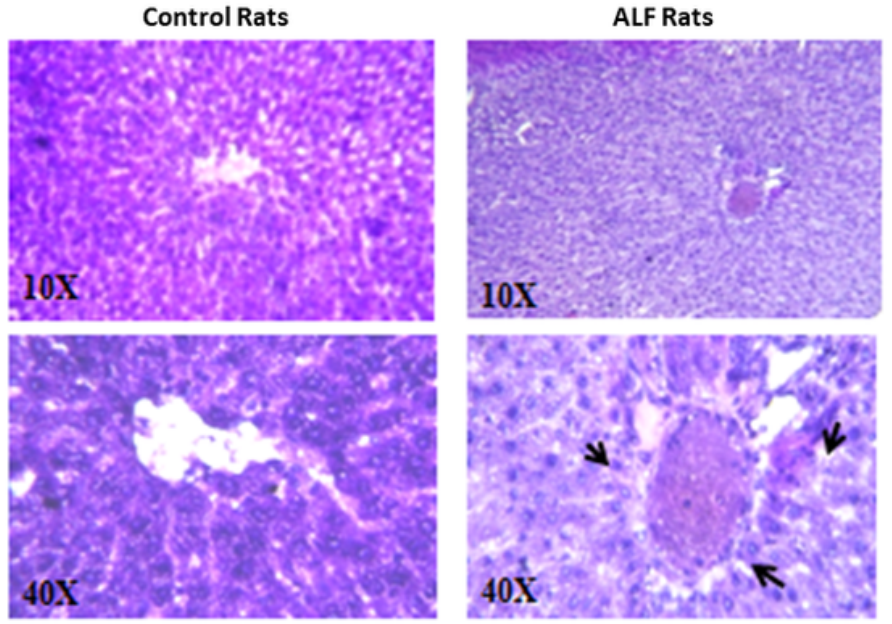

Fig-1

\section{Figure 1}

Light micrographs of H\&E-stained liver sections from control (a) and ALF (b) rats. Arrowheads show centrizonal necrosis in the liver cells. Cells with small nuclear stains indicate infiltration of neutrophils and mononuclear lymphocytes 


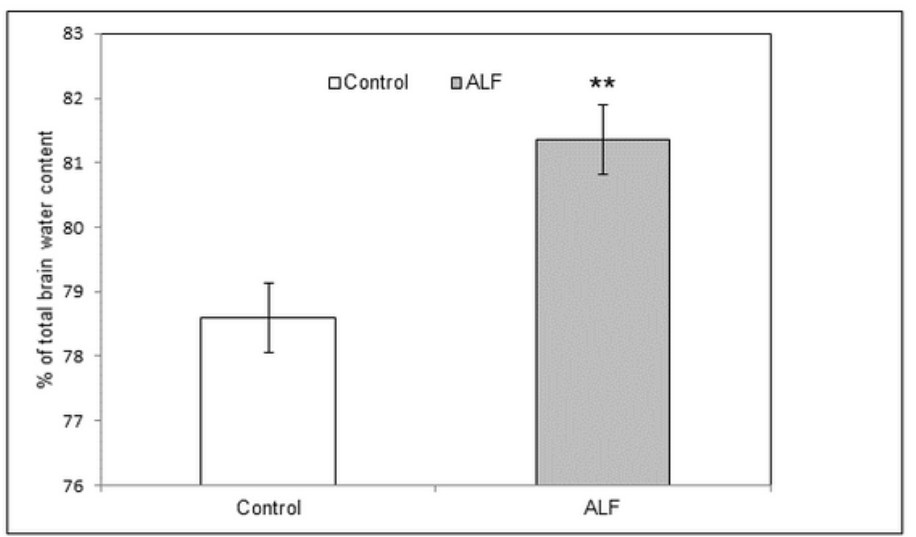

Fig-2

\section{Figure 2}

Percentage of total brain water content was found to be increased significantly in whole brain of ALF rats. ${ }^{*} \mathrm{p}<0.01$ (Control vs ALF rats) 

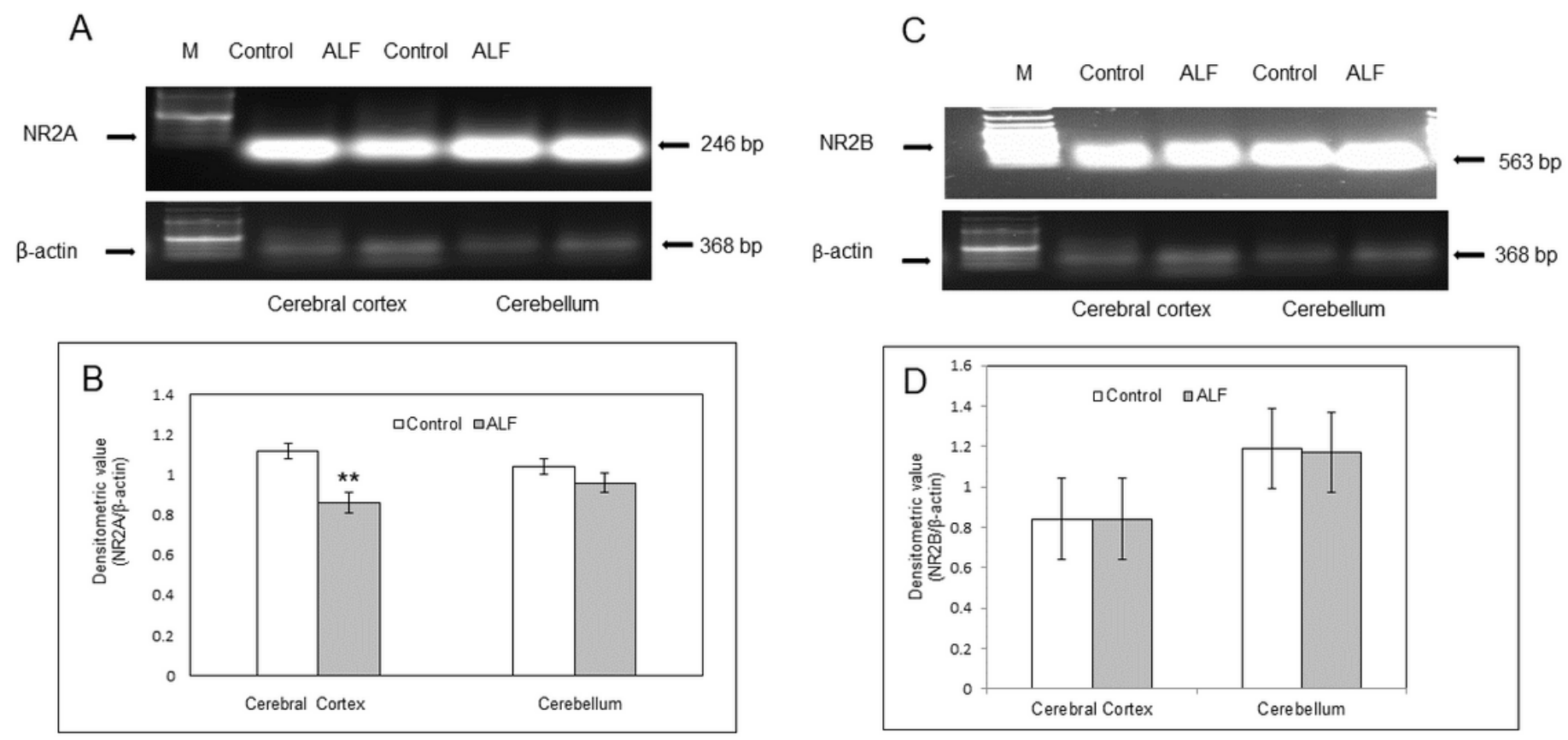

Fig-3

\section{Figure 3}

RT-PCR products of NR2A \& NR2B gene ( 25 cycles) from cerebral cortex and cerebellum of ALF rats; (A) Representative photographs of RT PCR for NR2A and (B) normalized densitometric values of NR2A / $\beta$ actin from 3 PCR repeats, ${ }^{*} p<0.01$ (Control vs ALF rats); (C) Representative photographs of RT PCR for NR2B and (D) normalized densitometric values of NR2B / $\beta$ actin from 3 PCR repeats 
A
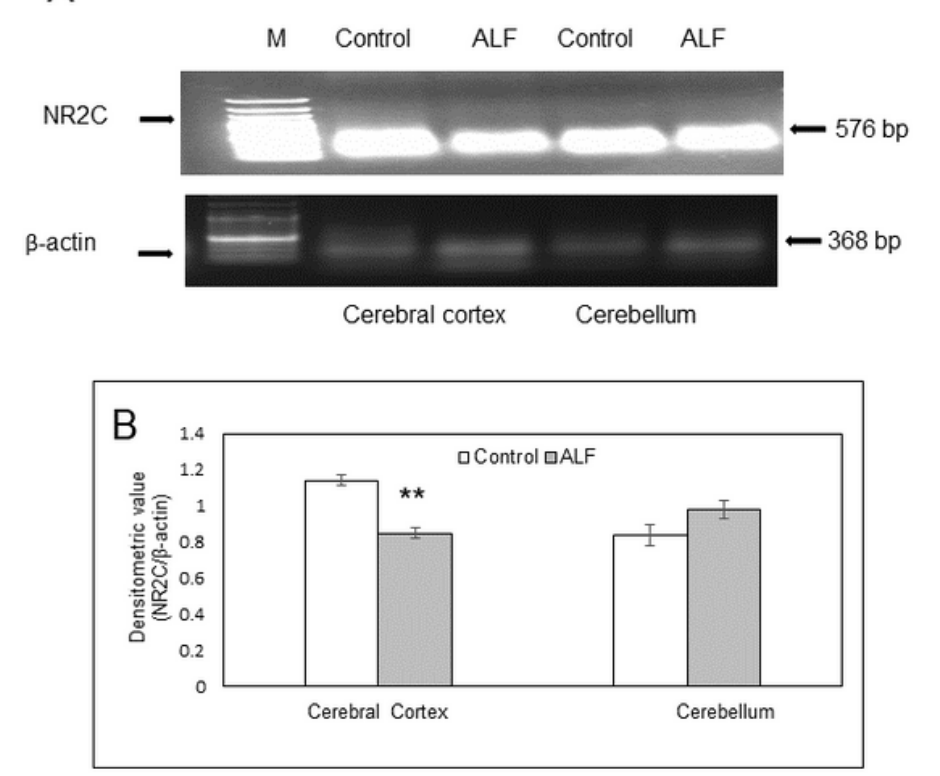

Fig-4
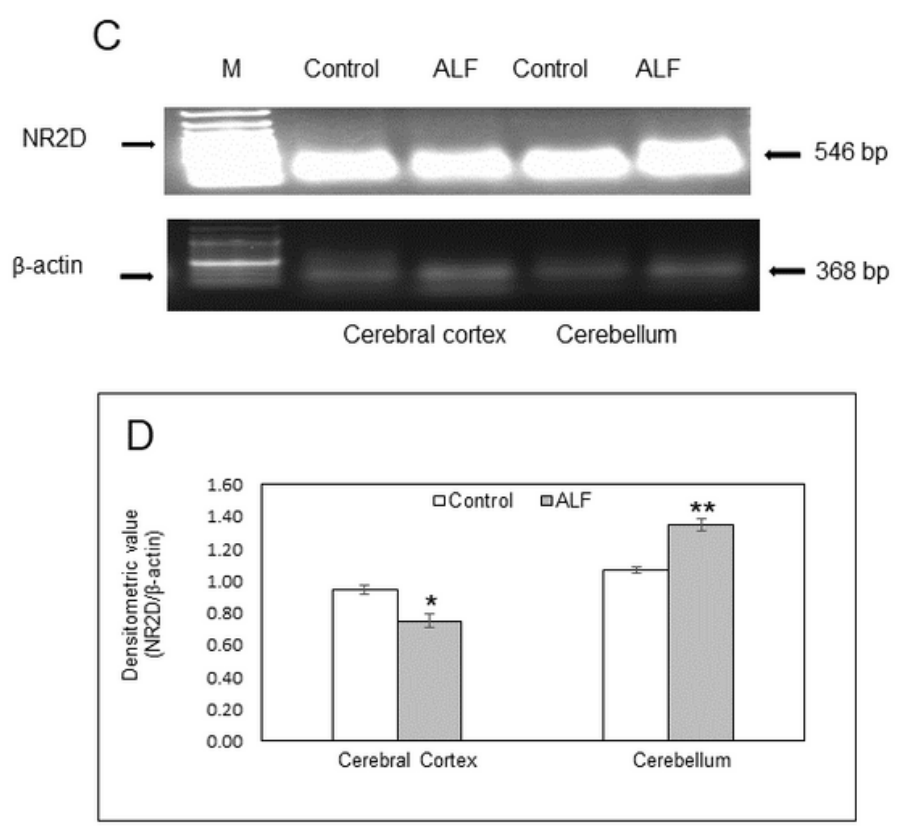

\section{Figure 4}

RT-PCR products of NR2C \& NR2D gene (25 cycles) from cerebral cortex and cerebellum of ALF rats; (A) Representative photographs of RT PCR for NR2C and (B) normalized densitometric values of NR2C / $\beta$ actin from 3 PCR repeats, ${ }^{\star *} p<0.01$ (Control vs ALF rats); (C) Representative photographs of RT PCR for NR2D and (D) normalized densitometric values of NR2D / $\beta$ actin from 3 PCR repeats, ${ }^{\star} p<0.05 \& * \star p<$ 0.01 (Control vs ALF rats) 
A
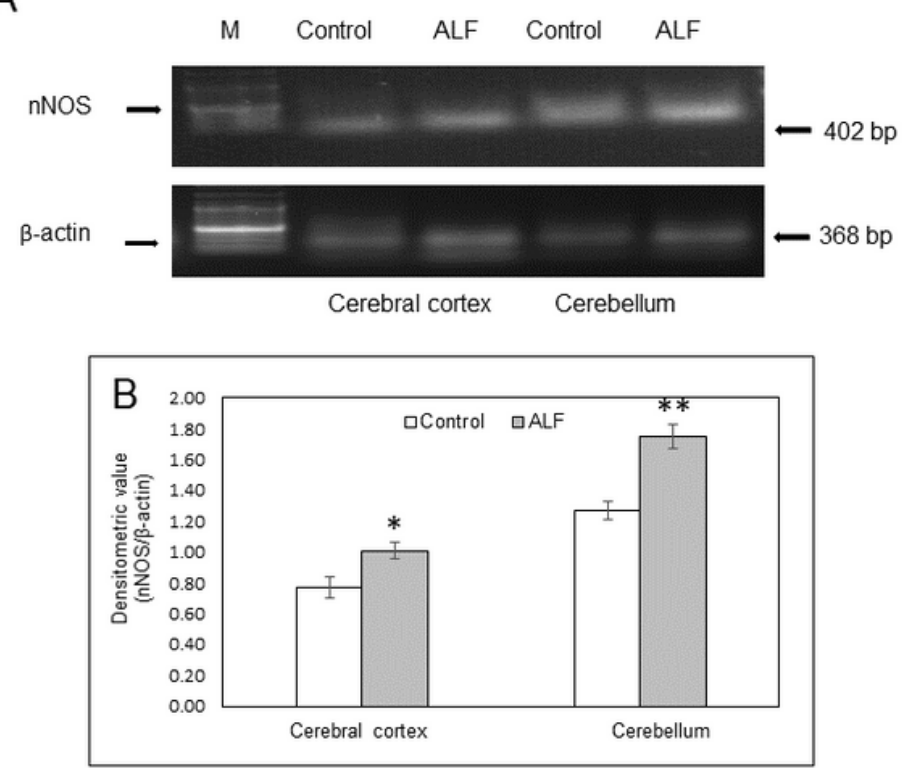

C
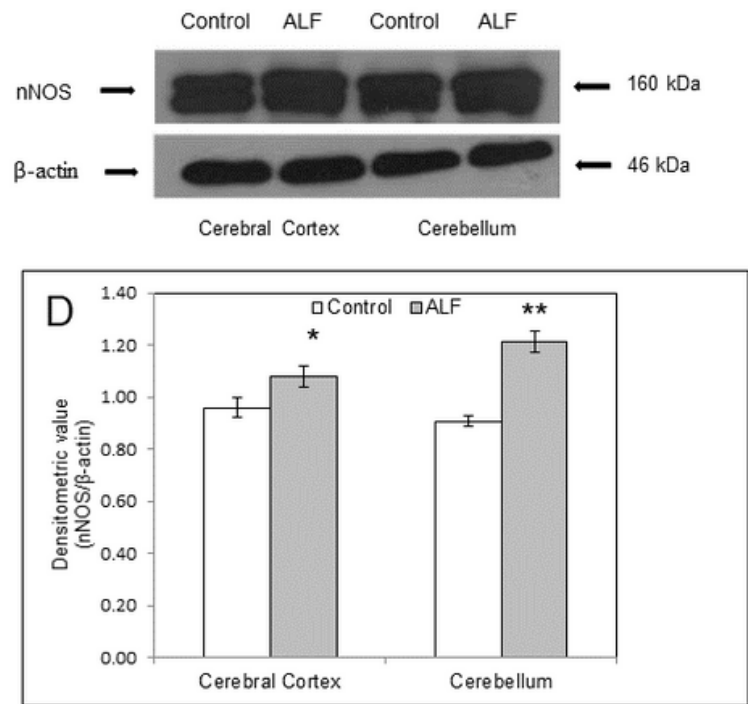

Fig-5

\section{Figure 5}

RT-PCR products of nNOS gene (30 cycles) \& western blot for nNOS from cerebral cortex and cerebellum of ALF rats; (A) Representative photographs of RT PCR for nNOS and (B) normalized densitometric values of $n N O S / \beta$ actin from 3 PCR repeats, * $p<0.05 \&{ }^{* *} p<0.01$ (Control vs ALF rats); (C) Representative photographs of western blot for $\mathrm{nNOS}$ and (D) normalized densitometric values of nNOS / $\beta$ actin from 3 western blots repeats, * $p<0.05 \&{ }^{* *} p<0.01$ (Control vs ALF rats) 

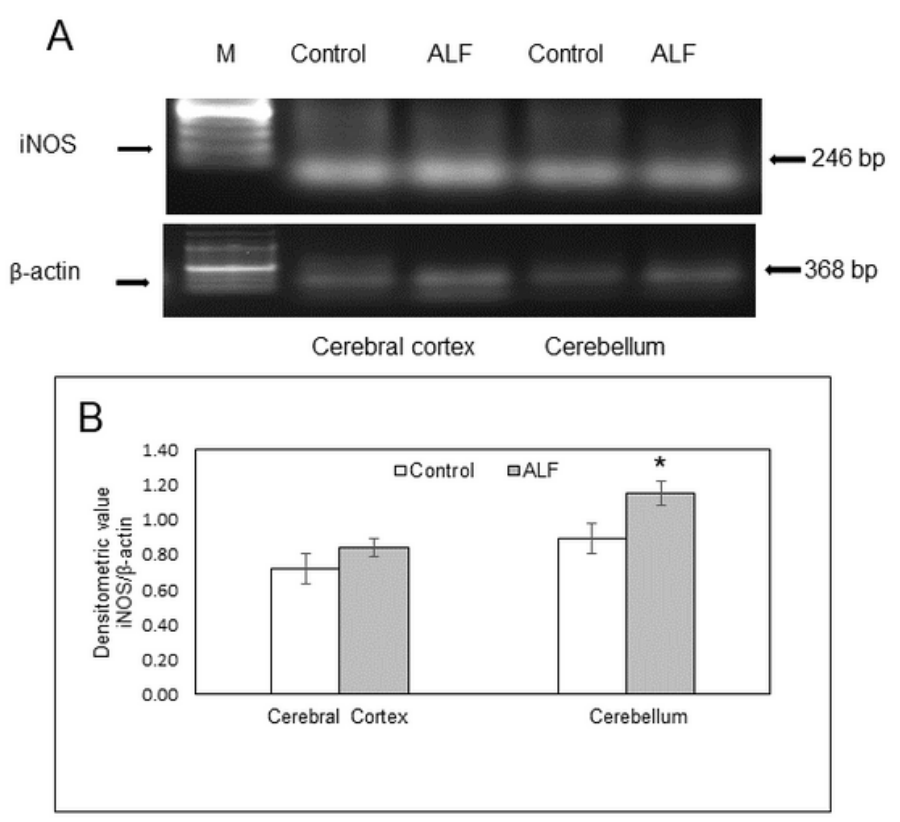

Fig-6

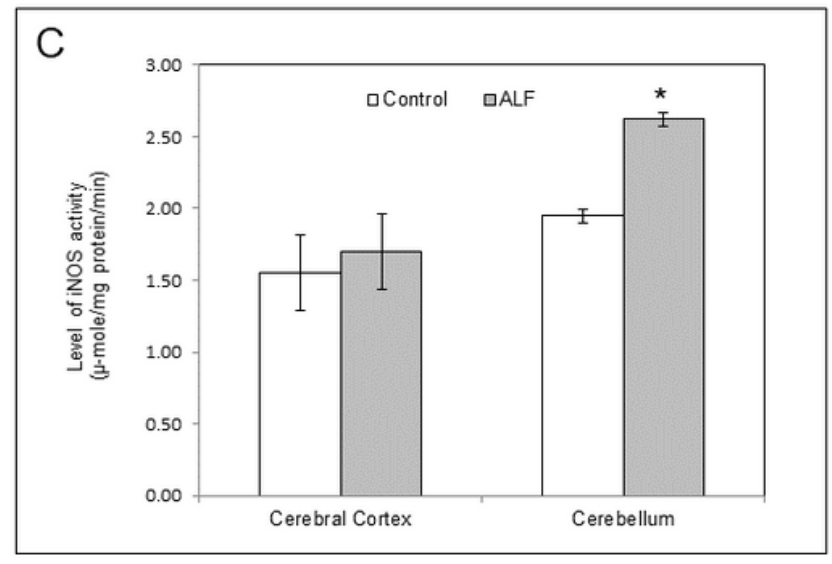

\section{Figure 6}

RT-PCR products of iNOS gene (30 cycles) and level of iNOS activity in cerebral cortex and cerebellum of ALF rats; (A) Representative photographs of RT PCR for iNOS and (B) normalized densitometric values of $n N O S / \beta$ actin from 3 PCR repeats, ${ }^{*} p<0.05$ (Control vs ALF rats); (C) The level of iNOS activity was found to be increased significantly in cerebellum of ALF rats, however, remain unchanged in cerebral cortex: Suggested brain region specific effect of ALF in respect to nitrosative factors, ${ }^{\star} p<0.05$ (Control vs ALF rats) 


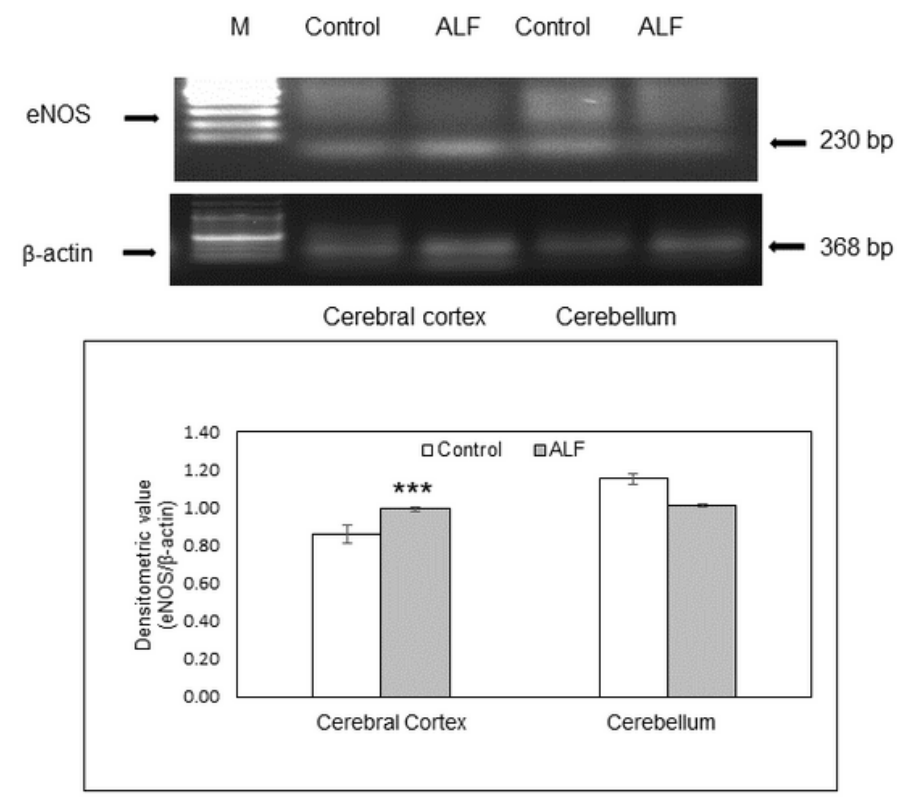

Fig-7

Figure 7

RT-PCR products of eNOS gene (30 cycles) from cerebral cortex and cerebellum of ALF rats.

Representative photographs of RT PCR for eNOS and normalized densitometric values of eNOS / $\beta$ actin from 3 PCR repeats, ${ }^{\star \star \star} p<0.001$ (Control vs ALF rats) 

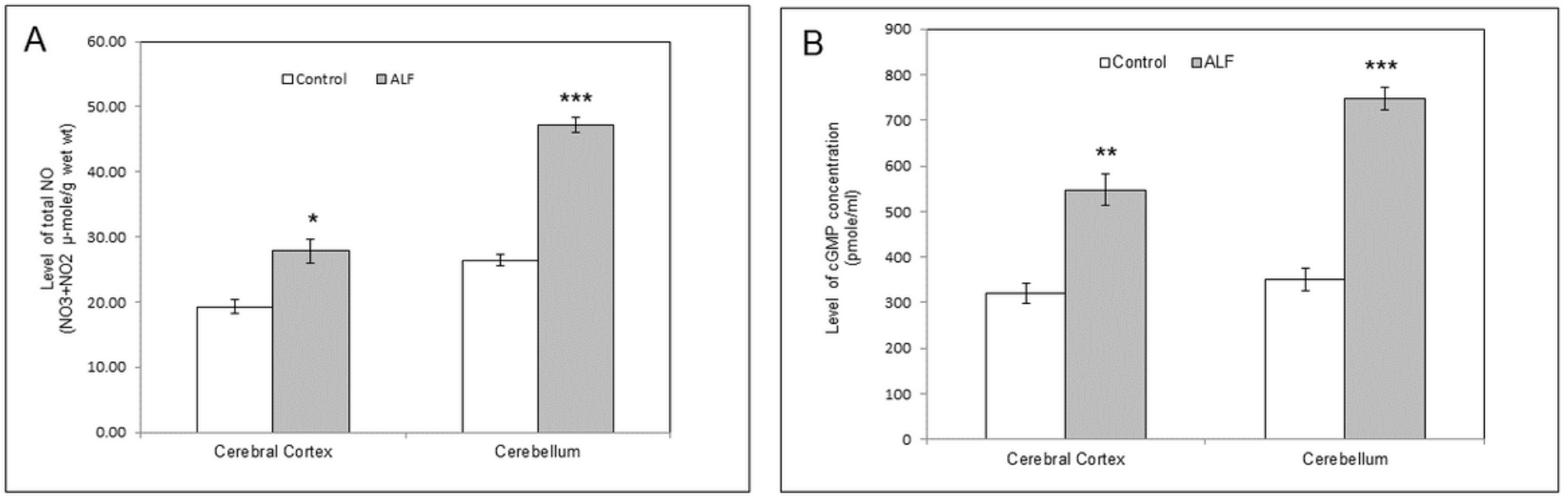

Fig-8

\section{Figure 8}

(A) Level of total nitric oxide was found to be increased significantly in both cerebral cortex and cerebellum of ALF rats, ${ }^{\star} p<0.05 \&{ }^{* \star \star} p<0.001$ (Control vs ALF rats); (B) Level of cGMP activity was found to be increased in both cerebral cortex and cerebellum of ALF rats, $* \star \star p p<0.001$ (Control vs ALF rats) 